\title{
Rural Women Entrepreneurs in Malaysia: What Drives Their Success?
}

\author{
Fatimah Hassan ${ }^{1}$, Aznarahayu Ramli ${ }^{1} \&$ Nasina Mat Desa ${ }^{1}$ \\ ${ }^{1}$ School of Distance Education, Universiti Sains Malaysia, Malaysia \\ Correspondence: Fatimah Hassan, School of Distance Education, Universiti Sains Malaysia, 11800 USM, \\ Penang, Malaysia. E-mail: hfatimah@usm.my
}

Received: January 13, 2014

Accepted: February 21, $2014 \quad$ Online Published: March 21, 2014

doi:10.5539/ijbm.v9n4p10

URL: http://dx.doi.org/10.5539/ijbm.v9n4p10

\begin{abstract}
This paper examine the entrepreneurial characteristics (risk taking, ability to explore, confidence and determination, willingness and initiative, vision, creativity and innovation, social networking and strategic thinking) that influence the success of rural women entrepreneur in business. The questionnaire is used as a data collection method that involves a total of 80 rural women entrepreneurs in the northern region of Peninsular Malaysia. Data collected were analysed using SPSS version 20 and SmartPLS 2.0. Findings from the Partial Least Squares analysis revealed that confidence and determination and vision are the main variables that influence business success of women entrepreneur in rural setting environment. In this regard, it is hoped that the findings of this study can help the parties concerned in the design and implementation of the agenda to stimulate the performance of this entrepreneurs to a higher level. It turns out this effort can contributes towards the development and transformation of the economy to achieve developed nation status and a high income by 2020. Implications, limitations as well as suggestions for future research are accordingly discussed in this paper.
\end{abstract}

Keywords: entrepreneur, rural area, women entrepreneurs, rural women entrepreneurs, entrepreneurial characteristics, business success

\section{Introduction}

The importance of entrepreneurial activities in regional economic development cannot doubt. These activities are the important source of economic growth and job creation (Friar \& Meyer, 2003) that improve the quality of life of individuals, families, communities and national economy development. Previous studies show that entrepreneurial activities can increase the Gross Domestic Product (GDP), employment opportunities, increase people's income and wealth, and bring forward the local population closer to the global economy (Reynolds, Hay \& Camp, 1999; Henderson, 2002). In Malaysia, entrepreneurship also becomes the main focus and priority in the formulation of Malaysian Government's policies and agenda. Starting from the sixth Malaysia Plan (RMK-6), the focus on entrepreneurship are increased through the incentives given to existing operators to double the efforts to penetrate the global market as well as encourage and attract a new generation to enter into this field. A lot of general actions plan implemented by the Malaysian Government on several key sectors such as industrial, privatization and entrepreneurship. Besides, there are also many entrepreneurial development programs undertaken by the Government in conjunction with private agencies and non-governmental organisations (NGOs).

Entrepreneurship is not a foreign field for women. In recent years, the number of women who enter the field showed encouraging improvements. The world hat witnessed a constant growth of women entrepreneurship and their contributions to the national economic and employment (Pitoska \& Charitoudi, 2011). The women-owned firms are also growing from time to time (Davidson \& Burke, 2004). For example, McKay (2001) reported that, in 1999 almost half of the small businesses in the United States are owned by women. In the meantime, Still and Timms (2000) stated that women played a major role in the growth of small businesses in Australia. In addition, the UK Government also estimates that nearly a quarter and a third of business firms in the country were owned by women (Fielden, Davidson, Dawe \& Makin, 2003). Orhan and Scott (2001) report that there are 26 percent of the total entrepreneurs in France are women. Mei Fun (2009) on the other hand reported that 16 percent of the small and medium size enterprise who involved in service sector, manufacturing and agriculture in Malaysia are owned by women. With the fact that the number of women entrepreneurs are increasing, there are also many stories of the success of most women entrepreneurs throughout the world (Alam, Jani \& Omar, 2011). Today, around the world, there are many women entrepreneurs have become millionaires. In fact, some of them seen 
more aggressive than men in terms of thoughts, feelings and actions (Suaibah et al., 2005). In this regard, it is the best idea to identify what are the characteristics they have that make them success in their business endeavour.

\section{Review of Literature}

\subsection{Business Success}

The success of a business or enterprise is measured from a variety of angles and tricks. For example, Perren (1999) and Amit, MacCrimmon, Zietsma and Oesch (2000) measuring business success through income, growth, wealth and profit as well as the ability of the business to remain longer in the industry. Watson, Horgarth-Scott and Wilson, (1998) and Dafna (2008) evaluated the success of the business through its ability to continue to carry out its trading activities. In addition, there are some researchers who measure the success of the business based on its ability to operate more than three years (Vesper, 1990; Watson et al., 1998; Taormina \& Lao, 2007). In addition, business success is also measured by the profitability of the acquired business and the average level of profit compared to the industry whether lower, equal to or higher than the average level of industry profits (Abdul Manaf, Omar \& Yee, 2012). Ashraf and Qureshi (2010) measure business success based on the company's financial strength, customer satisfaction and satisfaction of the entrepreneurs in their career.

\subsection{Factors Influencing Business Success}

Several factors that lead to achievement and success of entrepreneurs have been identified in previous literature. Among them are the internal and external environment (Delmar \& Wiklund, 2008), financial efficiency, management, location, investment in technology, production costs and network (Cassar, 2004). The success of a business or enterprise is also depending on the owners including honesty, friendliness (Benzing, Chu \& Kara, 2009; Makhbul \& Hasun, 2011; Benzing, Chu \& Bove, 2005; Benzing, Chu \& Callanan, 2005; Pollit, 2004; Kriger \& Hanson, 1999; Machan, 1999), creativity, perseverance, courage, confidence, humility, willingness to learn, strategic thinking, focused, strong determination and openness to new information (Elenurm \& Alas, 2009; Raffele, 2011). In addition, Ashraf and Qureshi (2010) develop a model by listing eight characteristics that drives the entrepreneurs' success in business including risk taking, confidence and determination, willingness and initiative, ability to explore, strategic thinking, creativity and innovative, vision and social networking.

\subsubsection{Risk Taking}

Risk taking is involve in a work or project that the outcome is unsure and has a probability of having lost. The aspects of risk-taking described the willingness of entrepreneurs to engage in the risky work or no bail. In another sense, it refers to the ability to cover possible loss turned over decisions or projects carried out in their business. Positive attitude towards risk will allow the entrepreneur success and enduring in its business. Thus, courage to take risk is the first step should be considered by the entrepreneurs (Tracy, 2007).

\subsubsection{Confidence and Determination}

Confidence and determination described the conviction and belief of the entrepreneurs against their business design that has been established as well as their courage in facing the challenge and failure.

\subsubsection{Willingness and Initiative}

Willingness and initiative refers the openness to the new ideas and products as well as the willingness to be the first to offer these product and services to the customer.

\subsubsection{Ability to Explore}

Ability to explore is on how entrepreneur is finding new business and opportunities for their company's growth and development.

\subsubsection{Strategic Thinking}

Strategic thinking refers to the process of making a decision effectively by using the resources and opportunities that exist for their business development.

\subsubsection{Creativity and Innovative}

Creativity and innovative refers to the ability of entrepreneurs to introduce as well as bringing out new ideas in their business. A creative and innovative entrepreneur is able to find faster, better, cheaper, easier ways to produce and deliver their products and services (Tracy, 2007).

\subsubsection{Vision}

Vision is the entrepreneurs' ability to make long-term plans and consider the possibilities of future impact on 
their business.

\subsubsection{Social Networking}

Social networking refers to friendliness and desire to interweave the relationship with other entrepreneurs.

\section{Research Model}

Based on the discussion in the review of the literature, this study was developed to explore the entrepreneurial characteristics of rural women entrepreneurs in Malaysia that affect their success in business by using the model recommended by Ashraf and Qureshi (2010). Figure 1 show a research model applied in this study.

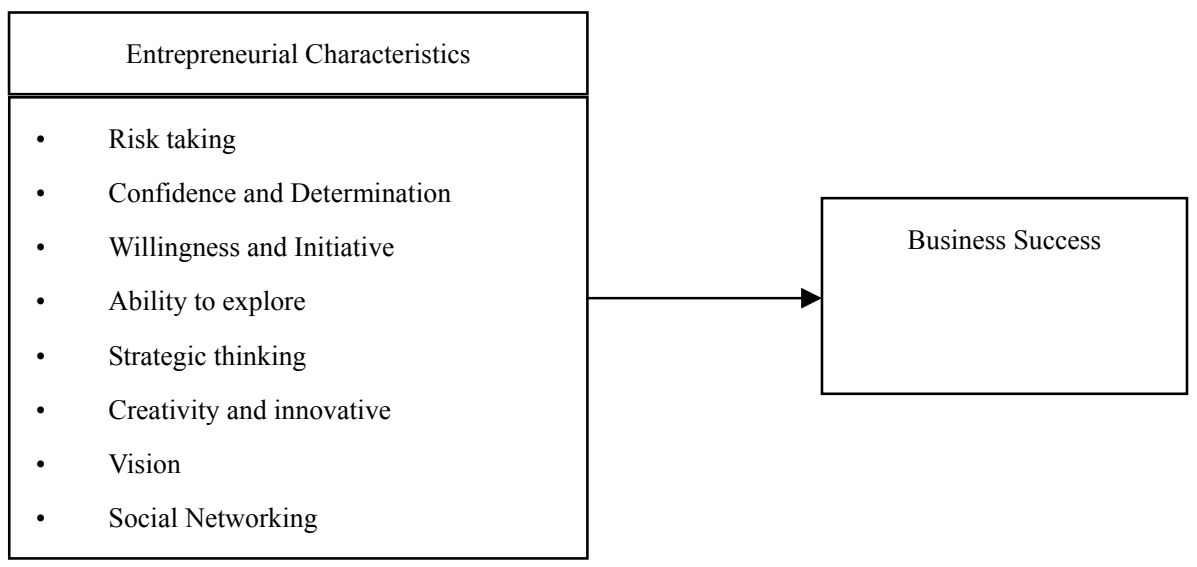

Figure 1. Research model

\section{Methodology}

\subsection{Research Design and Sampling}

This study involving a total of 80 women entrepreneurs in Northern Region of Peninsular Malaysia (Kedah, Perlis \& Penang). These entrepreneurs have been selected from a list provided by several agencies such as Amanah Ikhtiar Malaysia (AIM), Kedah Regional Development Authority (KEDA) and Penang Regional Development Authority (PERDA) who in charge of rural entrepreneur development programme in Malaysia. A breakdown of the respondents involved in accordance with the list provided by the agencies is provided in Table 1.

Table 1. Breakdown of the respondents

\begin{tabular}{lll}
\hline AGENCIES & TOTAL RESPONDENTS & STATES \\
\hline Amanah Ikhtiar Malaysia & 30 & Kedah and Perlis \\
Kedah Regional Development Authority & 20 & Kedah \\
Penang Regional Development Authority & 30 & Penang \\
\hline
\end{tabular}

The selection of the sample is based on the availability and willingness of the women entrepreneurs to be the respondents in this study. The researchers have contact them via phone in order to obtain approval to participate in the survey conducted. From the 90 entrepreneurs being called, only 80 of them expressed consent to participate in this survey. Data collection was carried out from December until February 2013. A set of questionnaire has been developed as an instrument and distributed through three methods by which through telephone conversations, email and face to face. The majority of respondents more comfortable to answer this survey through telephone conversations and emails as compared to face-to-face methods due to time constraints and the hustle factor.

\subsection{Measurement}

This study applied survey method as a study measurement. The survey instrument is divided into 4 parts which were adapted from previous research (Suaibah et al., 2005; Siti Norliza, 2005; Ashraf \& Qureshi, 2010). The breakdown of the instrument is provided in Table 2 . 
Table 2. Survey instruments

\begin{tabular}{lll}
\hline PARTS & CONTENTS & TOTAL QUESTIONS \\
\hline Part A & Personal Information & 11 \\
& $-\quad$ Source: Suaibah et al. (2005) & \\
Part B & Business Information & 9 \\
& $-\quad$ Source: Siti Norliza (2005) & \\
Part C & Entrepreneurial Characteristics & 20 \\
& $-\quad$ Source: Ashraf dan Qureshi (2010) & \\
Part D & Business Success & 4 \\
& $-\quad$ Source: Ashraf dan Qureshi (2010) & \\
\hline
\end{tabular}

Based on Table 2, Part A contains questions pertaining to the respondent's personal information such as age, marital status, academic, business, employment reasons to engage on before dealing, the age when starting a business as well as confirmation of whether or not have attend any training, courses or entrepreneurial workshop. Part B also ask about the background of the business such as type of business, number of employees, the amount of initial capital, the capital resources and business performance over the previous year. Part $\mathrm{C}$ contains the questions aimed at identifying entrepreneurial characteristics owned by entrepreneurs while part $\mathrm{D}$ contains questions that identify the level of success of the entrepreneurs in the business. Both section $\mathrm{C}$ and $\mathrm{D}$ is measured using the Likert Scale 7 levels $(1=$ strongly disagree, $7=$ strongly agree $)$.

\section{Results and Discussion}

\subsection{Respondent Profile}

This study involved a total of 80 women entrepreneurs. Table 3 show the profile of the respondents involved in this study.

Table 3. Respondent profile

\begin{tabular}{|c|c|c|c|}
\hline Item & Description & Frequency & Percentage \\
\hline \multirow[t]{4}{*}{ Age } & $21-30$ years old & 1 & 1.25 \\
\hline & $31-40$ years old & 34 & 42.5 \\
\hline & $41-50$ years old & 33 & 41.25 \\
\hline & 51 years old and above & 12 & 15.0 \\
\hline \multirow[t]{3}{*}{ Marital Status } & Single & 1 & 1.25 \\
\hline & Married & 71 & 88.75 \\
\hline & Widow/ Divorced & 8 & 10.0 \\
\hline \multirow[t]{6}{*}{ Academic Qualification } & No formal education & 3 & 3.75 \\
\hline & Primary School & 6 & 7.50 \\
\hline & $\mathrm{PMR} / \mathrm{SRP}$ & 10 & 12.5 \\
\hline & $\mathrm{SPM} / \mathrm{MCE}$ & 45 & 56.25 \\
\hline & STPM / Certificate & 9 & 11.25 \\
\hline & Diploma & 7 & 8.75 \\
\hline \multirow[t]{4}{*}{ Family members who become entrepreneurs } & None & 39 & 48.75 \\
\hline & Yes (Parent, Children, Siblings) & 41 & 51.25 \\
\hline & Children & & \\
\hline & Siblings & & \\
\hline \multirow[t]{6}{*}{ Reasons for venturing into a business } & Less satisfied with previous employment & 2 & 2.5 \\
\hline & As a source of income & 39 & 48.75 \\
\hline & Government's support & 1 & 1.25 \\
\hline & Family's support & 1 & 1.25 \\
\hline & Interest in business & 31 & 38.75 \\
\hline & Business inherited by family & 6 & 7.5 \\
\hline \multirow[t]{3}{*}{ Previous jobs before venturing into business } & Does not work/housewife & 50 & 62.5 \\
\hline & Public servants & 1 & 1.25 \\
\hline & Working in the private sector & 29 & 36.25 \\
\hline Monthly income prior to becoming an entrepreneur & RM1000 and below & 58 & 72.5 \\
\hline
\end{tabular}




\begin{tabular}{llll}
\hline & RM1001 - RM2000 & 18 & 22.5 \\
& RM2001 - RM3000 & 4 & 5.0 \\
Monthly income after becoming entrepreneurs & RM2001 - RM3000 & 12 & 15.0 \\
& RM3001 - RM4000 & 20 & 25.0 \\
& RM4001 - RM5000 & 27 & 33.75 \\
& RM5001 and above & 21 & 26.25 \\
\hline
\end{tabular}

Based on Table 3, majority of the respondents are 31 to 40 years old (42.5\%), have been married $(88.75 \%)$ and hold Malaysian Certificate of Education (SPM/MCE) (56.25\%). Most of them have family members (parent, children and siblings) who are also involved in business and entrepreneurship (51.25\%). Majority of them never worked before (62.5\%) and involving in entrepreneurship is their main source of income (48.75\%). Before involving in business field, most of them did not have personal income or even having not more than RM1000 per month (72.5\%). However, they managed to increase their monthly income whereby majority of them earned more than RM4000 per month after involving in business and entrepreneurship field (33.75\%).

\subsection{Business Profile}

Table 4 show the business profile of the respondents involved in this study.

Table 4. Business profile

\begin{tabular}{|c|c|c|c|}
\hline Item & Description & Frequency & Percentage \\
\hline \multirow[t]{3}{*}{ The status of business organization } & Sole proprietorship & 62 & 77.5 \\
\hline & Partnership & 10 & 12.5 \\
\hline & Private limited company & 8 & 10.0 \\
\hline \multirow[t]{10}{*}{ Type of business/industry } & Foods and beverages & 53 & 66.25 \\
\hline & Agriculture & 7 & 8.75 \\
\hline & Retailing & 5 & 6.25 \\
\hline & Beauty, make-up and grooming & 3 & 3.75 \\
\hline & Contractors and Construction & 1 & 1.25 \\
\hline & Pharmacy & 2 & 2.5 \\
\hline & Sewing and clothing & 5 & 6.25 \\
\hline & Printing services & 2 & 2.5 \\
\hline & Hospitality and tourism & 1 & 1.25 \\
\hline & Chemicals/ bleach/ detergent & 1 & 1.25 \\
\hline \multirow[t]{4}{*}{ Period of doing business } & $4-5$ years & 3 & 3.75 \\
\hline & $6-7$ years & 7 & 8.75 \\
\hline & $8-9$ years & 20 & 25.0 \\
\hline & 10 years and above & 50 & 62.5 \\
\hline \multirow[t]{6}{*}{ Capital when starting a business } & RM1,000 and below & 19 & 23.75 \\
\hline & RM1,001 - RM3,000 & 25 & 31.25 \\
\hline & RM3,001 - RM5,000 & 8 & 10.0 \\
\hline & RM5001 - RM7000 & 8 & 10.0 \\
\hline & RM7001 - RM9000 & 3 & 3.75 \\
\hline & RM9001 and above & 17 & 21.25 \\
\hline \multirow[t]{4}{*}{ Sources of capital } & Own savings & 32 & 40.0 \\
\hline & Loans from family & 8 & 10.0 \\
\hline & Inheritance & 4 & 5.0 \\
\hline & Loans from institutions / associations & 36 & 45.0 \\
\hline \multirow[t]{3}{*}{ Business performance compared to last year } & Increase & 78 & 97.5 \\
\hline & Decrease & 1 & 1.25 \\
\hline & No change & 1 & 1.25 \\
\hline
\end{tabular}

According to Table 4, majority of the entrepreneurs run their business as a sole proprietorship (77.5\%) and in food and beverages industry (66.25\%). Most of them have been doing business for more than 10 years $(62.5 \%)$ and started with capital RM3000 and below (55.1\%) from loans with institutions/associations (45\%) as well as 
their own savings $(40.0 \%)$. Majority of them declared that their business performance increased from the previous year $(97.5 \%)$.

\subsection{Measurement Model}

The measurement model was tested for convergent validity through factor loadings, composite reliability (CR) and average variance extracted (AVE) (Hair, Black, Babin \& Anderson, 2010; Hulland, 1999; Tenenhaus, Vinzi, Chatelin \& Lauro, 2005). Table 5 shows the results of convergent validity.

Table 5. Convergent validity

\begin{tabular}{|c|c|c|c|c|c|c|c|}
\hline Construct & Items & Loading & $\begin{array}{l}\text { Composite } \\
(\mathrm{CR})\end{array}$ & Reliability & $\begin{array}{l}\text { Average } \\
\text { (AVE) }\end{array}$ & Variance & Extracted \\
\hline \multirow[t]{3}{*}{ Risk Taking } & $\mathrm{C} 1$ & 0.827 & 0.895 & & 0.739 & & \\
\hline & $\mathrm{C} 2$ & 0.871 & & & & & \\
\hline & $\mathrm{C} 3$ & 0.880 & & & & & \\
\hline \multirow[t]{2}{*}{ Ability to Explore } & $\mathrm{C} 4$ & 0.929 & 0.889 & & 0.800 & & \\
\hline & $\mathrm{C} 5$ & 0.859 & & & & & \\
\hline \multirow[t]{3}{*}{ Confidence and determination } & C6 & 0.799 & 0.822 & & 0.607 & & \\
\hline & $\mathrm{C} 7$ & 0.689 & & & & & \\
\hline & $\mathrm{C} 8$ & 0.842 & & & & & \\
\hline \multirow[t]{2}{*}{ Willingness and initiative } & C9 & 0.885 & 0.900 & & 0.818 & & \\
\hline & $\mathrm{C} 10$ & 0.924 & & & & & \\
\hline \multirow[t]{2}{*}{ Strategic Thinking } & $\mathrm{C} 11$ & 0.944 & 0.841 & & 0.727 & & \\
\hline & $\mathrm{C} 12$ & 0.948 & & & & & \\
\hline \multirow[t]{2}{*}{ Creativity and innovation } & $\mathrm{C} 13$ & 0.912 & 0.928 & & 0.866 & & \\
\hline & $\mathrm{C} 14$ & 0.948 & & & & & \\
\hline \multirow[t]{2}{*}{ Social Networking } & $\mathrm{C} 15$ & 0.907 & 0.717 & & 0.572 & & \\
\hline & $\mathrm{C} 17$ & 0.566 & & & & & \\
\hline \multirow[t]{2}{*}{ Vision } & $\mathrm{C} 19$ & 0.781 & 0.945 & & 0.895 & & \\
\hline & $\mathrm{C} 20$ & 0.920 & & & & & \\
\hline \multirow[t]{4}{*}{ Business Success } & D21 & 0.894 & 0.876 & & 0.644 & & \\
\hline & D22 & 0.914 & & & & & \\
\hline & D23 & 0.604 & & & & & \\
\hline & D24 & 0.759 & & & & & \\
\hline
\end{tabular}

Referring to Table 5 , for factor loadings, the cut-off criterion of 0.5 is to be considered as a strong factor loading coefficient (Hair et al., 2010; Hulland, 1999). In this case, items C16 and C18 have been deleted. In addition, Table 5 also shows the composite reliability values construct range from .717 to .945 . These exceeded the recommended value of 70 (Chin, 1998; Hair, Anderson, Tatham, \& Black, 1998). The AVE also exceeded the recommended value of .50 (Barclay, Thompson \& Higgins, 1995; Chin, 1998; Hair et al., 1998) which range from .572 to .895 and these proves the constructs expected to be related are very much so.

\subsection{Discriminant Validity}

Discriminant validity is the extent to which the measures are not a reflection of some other variables and it is indicated by the low correlations between the measure of interest and the measures of other constructs (Cheung \& Lee, 2010). The discriminant validity can be demonstrated in a correlation matrix which includes the correlations between different constructs in the lower left off-diagonal elements of the matrix, and the square roots of AVE calculated for each of the constructs along the diagonal (Teo, 2009). Table 6 shows the details of this analysis. 
Table 6. Discriminant validity

\begin{tabular}{|c|c|c|c|c|c|c|c|c|c|}
\hline & $(1)$ & $(2)$ & $(3)$ & $(4)$ & $(5)$ & $(6)$ & $(7)$ & $(8)$ & $(9)$ \\
\hline (1) Confidence and determination & 0.779 & & & & & & & & \\
\hline (2) Creativity and innovation & 0.112 & 0.931 & & & & & & & \\
\hline (3) Ability to Explore & 0.479 & 0.372 & 0.894 & & & & & & \\
\hline (4) Willingness and initiative & 0.485 & 0.146 & 0.545 & 0.905 & & & & & \\
\hline (5) Social Networking & 0.252 & 0.326 & 0.258 & 0.260 & 0.756 & & & & \\
\hline (6) Risk Taking & 0.561 & 0.348 & 0.772 & 0.628 & 0.293 & 0.860 & & & \\
\hline (7) Vision & 0.448 & 0.334 & 0.538 & 0.796 & 0.219 & 0.580 & 0.946 & & \\
\hline (8) Business Success & 0.553 & 0.363 & 0.539 & 0.512 & 0.371 & 0.622 & 0.599 & 0.802 & \\
\hline (9) Strategic Thinking & 0.077 & 0.168 & 0.090 & 0.036 & -0.013 & 0.118 & 0.031 & 0.110 & 0.85 \\
\hline
\end{tabular}

Notes. Diagonals represent the square root of the AVE while the off-diagonals represent correlations.

From Table 6, the measurement demonstrates that there is adequate discriminant validity, since the diagonal elements are significantly greater than the off-diagonal elements in the corresponding rows and columns. For example, diagonal value for confidence and determination is .779 which is greater than the off-diagonal values located in the corresponding rows such as $.112, .479, .485$, etc. In total, the measurement model has demonstrated adequate convergent validity and discriminant validity.

\subsection{Hypotheses Testing}

The hypotheses of this study were tested by examining the path coefficients $(\beta)$ through structural equation modelling using Partial Least Squares (PLS) approach. The path coefficients generated by PLS provide an indication of the relationships and can be used similar to the traditional regression coefficients (Gefen, Straub \& Boudreau, 2000). The bootstrapping technique was used to obtain the t-values of each coefficient (Bakshi \& Krishna, 2009; Chin, 2010; Efron \& Tibshirani, 1993). The t-values of the parameter indicate the strength of the relationship the parameter represents; therefore the higher the t-value, the stronger the relationship is (Huang, Lin \& Chuang, 2007). In addition, $\mathrm{R}^{2}$ values of the endogenous (dependent) constructs indicate whether a particular PLS model accomplishes the objective of maximizing the variance explained (Hulland, 1999; Schepers, Wetzels \& de Ruyter, 2005). Results of the analysis are depicted in Figure 2 and Table 7.

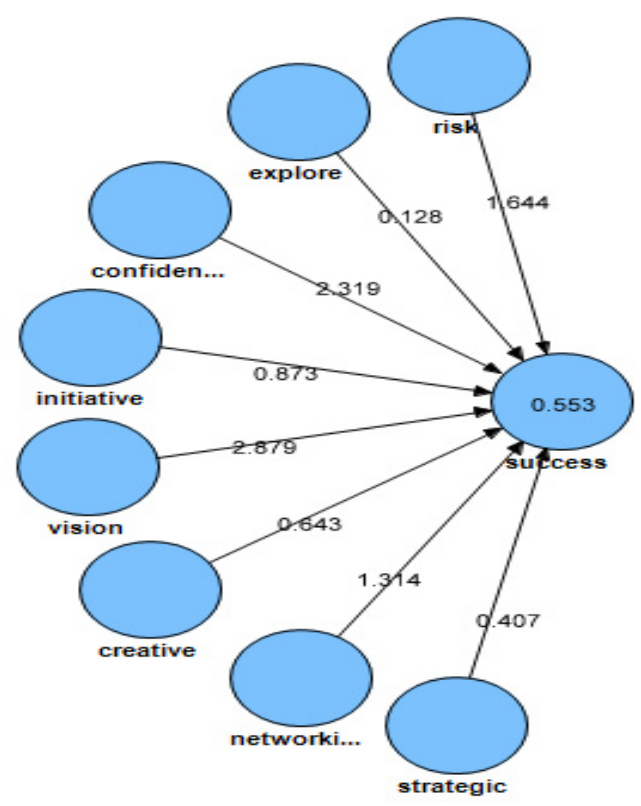

Figure 2. Results of the path analysis 
Table 7. Path coefficients and hypotheses testing

\begin{tabular}{|c|c|c|c|c|}
\hline \multicolumn{2}{|c|}{ Hypotheses } & \multirow{2}{*}{$\begin{array}{l}\text { Path Coefficients (Beta) } \\
0.256\end{array}$} & \multirow{2}{*}{$\frac{t \text {-Value }}{1.644}$} & \multirow{2}{*}{$\begin{array}{l}\text { Results } \\
\text { Not Supported }\end{array}$} \\
\hline H1 & risk -> success & & & \\
\hline $\mathrm{H} 2$ & explore -> success & 0.022 & 0.128 & Not Supported \\
\hline $\mathrm{H} 3$ & confidence -> success & $0.244 * *$ & 2.319 & Supported \\
\hline $\mathrm{H} 4$ & initiative -> success & -0.127 & 0.873 & Not Supported \\
\hline H5 & vision -> success & $0.369 * * *$ & 2.879 & Supported \\
\hline H6 & creative $->$ success & 0.076 & 0.644 & Not Supported \\
\hline $\mathrm{H} 7$ & networking -> success & 0.157 & 1.314 & Not Supported \\
\hline $\mathrm{H} 8$ & strategic $->$ success & 0.042 & 0.407 & Not Supported \\
\hline \multicolumn{5}{|c|}{$\mathrm{R}^{2}=0.553$} \\
\hline
\end{tabular}

The results in Table 7 indicated that confidence and determination $(\beta=0.244, p<.05)$ and vision $(\beta=0.369, p$ $<.01)$ were positively related to business success, explaining $55.3 \%\left(\mathrm{R}^{2}\right)$ of the variance present in business success. On the other hand, creativity and innovation, ability to explore, willingness and initiative, social networking, risk taking and strategic thinking was not a significant predictor of business success. Thus, only H3 and $\mathrm{H} 5$ were supported whereas $\mathrm{H} 1, \mathrm{H} 2, \mathrm{H} 4, \mathrm{H} 6, \mathrm{H} 7$ and $\mathrm{H} 8$ were not supported.

This result is consistent with the study done by Ashraf and Qureshi (2010) who found that confidence and determination is the critical contributor in the entrepreneurship success. Entrepreneurs with confidence always know that they can achieve their dream and they will determine to succeed no matter what gets in their way. On the other hand, numerous researchers stressed that risk taking behaviour is very familiar with entrepreneurs (Brockhaus, 1976; Fuad, Bohari \& Hin, 2011) and this behaviour should be posited by the entrepreneurs in order to success in their business. However, this study found that risk taking was not a significant contributor for the entrepreneurs' business success. This result is similar to Paul, Hamzah, Samah, Ismail \& D'Silva's (2013) study who found that Malay entrepreneurs are reluctant to take risk to go further in their business. In addition, Ashraf and Qureshi (2010), Puri and Robinson (2006) and Norton and More (2006) claimed that the entrepreneurs are not risky as the entrepreneurs' perception on the risk is different from non-entrepreneurs because entrepreneurs have vision. Interestingly, this study support that argument whereby the results of the analysis founded that, vision is one of the main contributors for business success. Entrepreneurs who have vision would have the ability to make long-term plans and consider the possibilities of future impact on their business expansion (Ashraf \& Qureshi, 2010). Therefore, entrepreneurs who want to succeed in business should have a long-term mission and vision. For example, they must have a business plan for at least the next three years and consider the possibilities of future developments affecting their business. In addition, it is necessary for entrepreneurs to always identify their main competitors and learn from the marketing strategy used by the competitors.

\section{Conclusion and Recommendations}

The aim of this study is to determine the entrepreneurial characteristics risk taking, ability to explore, confidence and determination, willingness and initiative, vision, creativity and innovation, social networking and strategic thinking) that influence the success of rural women entrepreneur in business. The findings indicated that, in order to succeed in the business endeavour, the women entrepreneurs need to have confidence and determination as well as vision. Based on these findings, the researchers propose that to increase the number of successful women entrepreneurs in Malaysia, other entrepreneurs should emulate entrepreneurs who have been successful. Key entrepreneurial traits possessed by successful entrepreneurs should be instilled in every other entrepreneur if they want to succeed in their business. The responsible parties for entrepreneurs' development programs also recommended to play their roles not only in terms of providing capital but also provides programs that can help entrepreneurs increase their confidence, courage and their openness to challenge in business. This can be accomplished through workshops, training and motivational courses that related to business and entrepreneurship. In Malaysia, the responsible parties are including The Council of Trust for the People (MARA), Amanah Ikhtiar Malaysia (AIM), Kedah Regional Development Authority (KEDA) and Penang Regional Development Authority (PERDA). In addition, the entrepreneurs would also be given more encouragement and support in terms of moral, financial and infrastructure so that their achievement can be upgraded to a higher level. These are in line with the national objective of National Key Result Areas (NKRA), 
Economic Transformation Program (ETP) and New Economic Models (NEM) which strives to produce innovative and brilliant entrepreneurial activities. This is because it has been proven that the activity was indeed able to improve the economic and better life of the local residents as well as contribute towards development and economic transformation of the country.

\section{Limitations and Suggestion for Future Research}

This study has devoted considerable attention to explain the relationship between entrepreneurial characteristics and business success. However, there are still some limitations which researchers aware of in this study. First, this study involves rural women entrepreneurs in Northern area of Malaysia thus, difficult to apply this study to other context of the world. it is because, its believed that what hold true for entrepreneur in one part of the world cannot be a legitimate basis for studies elsewhere (Renolds \& White, 1997; Gadenne, 1998; Drakopoulou \& Patra, 2002 cited by Kunene, 2009). Therefore, further research should be conducted in different setting to confirm the generalization of the same model. Second, it must be noted that, the model is just to find out the direct relationship between entrepreneurial characteristics and business success. As being reported in previous literatures, many factors influence business success including internal factors such as skills and knowledge (Makhbul \& Hasun, 2011; Chu, Benzing, \& McGee, 2007; Cox \& Jennings, 1995; Kozan, Oksoy \& Ozsoy, 2006), attitudes and behaviours (Makhbul \& Hasun, 2011; Benzing et al., 2009; Coy, Shipley, Omer \& Khan, 2007) and external factors such as government supports (Yusuf, 1995), market opportunity (Kozan et al., 2006; Lussier, 1995), availability of financial resources (Lee \& Stearns, 2012; Gundry \& Welsch, 2001) and supports from others (Levent, Masurel \& Nijkamp, 2003; Fielden \& Dawe, 2004). In addition, the results that found only two variables influencing the business success showed that there are variables that missing in this study. Therefore, future research should include other independent variables and intervening variables to the relationship with business success.

\section{Acknowledgements}

This research has been funded by Ministry of Education, Malaysia under Fundamental Research Grant Scheme (203/PJJAUH/6711207).

\section{References}

Abdul, M. A., Omar, N. H., \& Yee, L. K. (2012). Critical success factors of entrepreneurs in business. Journal of Social Sciences and Humanities, 7(1), 34-45.

Alam, S. S., Jani, M. F. M., \& Omar, N. A. (2011). An empirical study of success factors of women entrepreneurs in southern region in Malaysia. International Journal of Economics and Finance, 3(2), 166-175. http://dx.doi.org/10.5539/ijef.v3n2p166

Amit, R., MacCrimmon, K., Zietsma, C., \& Oesch, J. (2000). Does money matter? Wealth attainment as the motive for initiating growth-oriented technology ventures. Journal of Business Venturing, 16(2), 119-143.

Ashraf, M. F., \& Qureshi, T. M. (2010). Risk taking and essential success factors: A comparative analysis in 21 st century entrepreneurial dimensions. Mustang Journal of Business \& Ethics, 1, 99-119.

Bakshi, S., \& Krishna, S. (2009). Empirical analysis of the impact of virtuality on flexibility of virtual teams in software development projects. AMCIS 2009 Proceedings.

Barclay, D. W., Thompson, R., \& Higgins, C. (1995). The partial least squares (PLS) approach to causal modeling: Personal computer adoption and use an illustration. Technology Studies, 2(2), 285-309.

Benzing, C., Chu, H. M., \& Bove, R. (2005). The motivation, problems, and perceived success of entrepreneurs in Romania. Journal of the Academy of Business Administration, 10(1\&2), 73-88.

Benzing, C., Chu, H. M., \& Kara, O. (2009). Entrepreneurs in Turkey: A factor analysis of motivations, success factors, and problems. Journal of Small Business Management, 47(1), 58-91.

Benzing, C., Chu, H. M., \& Callanan, G. (2005). Regional comparison of the motivation and problems of Vietnamese entrepreneurs. Journal of Developmental Entrepreneurship, 10, 3-27. http://dx.doi.org/10.1142/S1084946705000033

Brockhaus, R. H. (1976). Locus of control and risk-taking propensity as entrepreneurial characteristic. $\mathrm{PhD}$ Dissertation. Seattle: Washington University.

Cassar, G. (2004). The financing of business start-ups. Journal of Business Venture, 19(2), 261-283.

Cheung, C. M. K., \& Lee, M. K. O. (2010). A theoretical model of intentional social action in online social networks. Decision Support Systems, 49(1), 24-30. http://dx.doi.org/10.1016/j.dss.2009.12.006 
Chin, W. W. (1998). The partial least squares approach for structural equation modeling. In George A., \& Marcoulides (Eds.), Modern Methods for Business Research, Lawrence Erlbaum Associates (pp. 295-336).

Chin, W. W. (2010). How to Write Up and report PLS Analyses. In V. E. Vinzi, W. W. Chin, J. Henseler, \& H. Wang (Eds.), Handbook of Partial Least Squares (pp. 655-690). Berlin: Springer-Verlag.

Chu, H. M., Benzing, C., \& McGee, C. (2007). Ghanaian and Kenyan entrepreneurs: A comparative analysis of their motivations, success characteristics and problems. Journal of Developmental Entrepreneurship, 12(3), 295-322. http://dx.doi.org/10.1142/S1084946707000691

Cox, C., \& Jennings, R. (1995). The foundation of success: The development and characteristics of British entrepreneurs and intrapreneurs. Leadership and Organizational Development Journal, 16(7), 4-9. http://dx.doi.org/10.1108/01437739510100892

Coy, S. P., Shipley, M. F., Omer, K., \& Khan, R. N. A. (2007). Factors contributory to success: A study of Pakistan's small business owners. Journal of Developmental Entrepreneurship, 12(2), 181-198.

Dafna, K. (2008). Managerial performance and business success: Gender differences in Canadian and Israeli entrepreneurs. Journal of Enterprising Communities: People and Places in the Global Economy, 2(4), 300-331.

Davidson, J. M., \& Burke, J. R. (2004). Women in management worldwide: facts, figures and analysis. Aldershot: Ashgate Publishing Company.

Delmar, F., \& Wiklund, J. (2008). The effect of small business managers' growth and motivation on firm growth: a longitudinal study. Entrepreneurship Theory and Practice, 32(3), 437-453. http://dx.doi.org/10.1111/j.1540-6520.2008.00235.x

Efron, B., \& Tibshirani, R. (1993). An introduction to the bootstrap. Boca Raton, FL: Chapman \& Hall.

Elenurm, T., \& Alas, R. (2009). Features of successful entrepreneurs in Estonia and changing organisational development challenges. Baltic Journal of Management, 4(3), 318-330. http://dx.doi.org/10.1108/17465260910991019

Fielden, L. S., Davidson, J. M., Dawe, J. A., \& Makin, J. P. (2003). Factors inhibiting the economic growth of female owned small businesses in North West England. Journal of Small Business and Enterprise Development, 10(2), 152-166. http://dx.doi.org/10.1108/14626000310473184

Fielden, S. L., \& Dawe, A. (2004). Entrepreneurship and social inclusion. Women in Management Review, 19(3), 139-142. http://dx.doi.org/10.1108/09649420410529843

Friar, J. H., \& Meyer, M. H. (2003). Entrepreneurship and start-ups in the Boston region: Factors differentiating high-growth ventures from micro-ventures. Small Business Economics, 21(2), 145-152.

Fuad, N., Bohari, A. M., \& Hin, C. W. (2011). Women entrepreneurs in the ICT-related business in Malaysia: A demographic survey. International Journal of Business and Management, 6(10), 127-137. http://dx.doi.org/10.5539/ijbm.v6n10p127

Gefen, D., Straub, D. W., \& Boudreau, M. C. (2000). Structural equation modelling and regression: Guidelines for research practice. Communications of the Association for Information Systems, 4(7), 1-79.

Gundry, L. K., \& Welsch, H. P. (2001). The ambitious entrepreneur: High growth strategies of female owned enterprises. Journal of Business Venturing, 16, 453-470. http://dx.doi.org/10.1016/S0883-9026(99)00059-2

Hair, J. E., Anderson, R. E., Tatham, R. L., \& Black, W. C. (1998). Multivariate data analysis (5th ed.). Upper Saddle River, NJ: Prentice-Hall.

Hair, J. F., Black, W. C., Babin, B. J., \& Anderson, R. E. (2010). Multivariate data analysis. In Upper Saddle River, NJ: Prentice-Hall.

Henderson, J. (2002). Building the rural economy with high-growth entrepreneurs. Retrieved from http://www.kansascityfed.org/Publicat/econrev/Pdf/3q02hend.pdf

Huang, J., Lin, Y., \& Chuang, S. (2007). Elucidating user behaviour of mobile learning: A perspective of the extended technology acceptance model. The Electronic Library, 25(5), 586-599. http://dx.doi.org/10.1108/02640470710829569

Hulland, J. S. (1999). Use of partial leasts quares (PLS) in strategic management research: A review of four

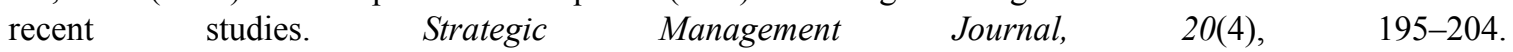
http://dx.doi.org/10.1002/(SICI)1097-0266(199902)20:2<195::AID-SMJ13>3.0.CO;2-7 
Kozan, M. K., Oksoy, D., \& Ozsoy, O. (2006). Growth plans of small business in Turkey: Individual and environmental influences. Journal of Small Business Management, 4(11), 114-129. http://dx.doi.org/10.1111/j.1540-627X.2006.00157.x

Kriger, M. P., \& Hanson, B. J. (1999). A value-based paradigm for creating truly healthy organizations. Journal of Organizational Change Management, 12(4), 302-317. http://dx.doi.org/10.1108/09534819910282144

Kunene, T. R. (2008). A critical analysis of entrepreneurial and business skills in SMEs in the textile and clothing industry in Johannesburg, South Africa. PhD thesis, University of Pretoria, Pretoria.

Lee, S. S., \& Stearns, T. M. (2012). Critical Success Factors in the Performance of Female-Owned Businesses: A Study of Female Entrepreneurs in Korea. International Journal of Management, 29(1), 3-18.

Levent, T. B., Masurel, E., \& Nijkamp, P. (2003). Diversity in entrepreneurship: Ethnic and female roles in urban economic life. International Journal Social Economic, 30(11), 1131-1161. http://dx.doi.org/10.1108/03068290310497495

Lussier, R. N. (1995). Start-up Business Advice from Business Owners to Would Be Entrepreneurs. SAM Advanced Management Journal, 60(1), 10-13.

Machan, T. R. (1999). Entrepreneurship and ethics. International Journal of Social Economics, 26(5), 596-608. http://dx.doi.org/10.1108/03068299910216103

Makhbul, Z. M., \& Hasun, F. M. (2011). Entrepreneurial Success: An Exploratory Study among Entrepreneurs. International Journal of Business and Management, 6(1), 116-125.

McKay, R. (2001). Women entrepreneurs: moving beyond family and flexibility. International Journal of Entrepreneurial Behaviour \& Research, 7, 148-165. http://dx.doi.org/10.1108/EUM0000000005764

Mei, F. C. (2009). Recognize the participation of women. Retreived from http://www.utusan.com.my/utusan/info.asp? $=2010 \& d t=0104 \&$ pub=utusan_malaysia\&sec $=$ Feminin \&pg $=\mathrm{f}$ e_01.htm

Norton, W. I., \& Moore, W. T. (2006). The Influence of Entrepreneurial Risk Assessment on Venture Launch or Growth Decisions. Small Business Economics, 26, 215-226. http://dx.doi.org/10.1007/s11187-004-5612-y

Orhan, M., \& Scott, D. (2001). Why women enter into entrepreneurship: An explanatory model. Women in Management Review, 16(5), 232-43. http://dx.doi.org/10.1108/09649420110395719

Paul, K. C., Hamzah, A., Samah, B. A., Ismail, I. A., \& D’Silva, J. L. (2013). Development of rural herbal entrepreneurship in malaysia. International Journal of Business and Management, 8(18), 95-100. http://dx.doi.org/10.5539/ijbm.v8n18p95

Perren, L. (1999). Factors in the growth of micro-enterprises: developing a framework. Journal of Small Business and Enterprise Development, 6(4), 366-385. http://dx.doi.org/10.1108/EUM0000000006691

Pitoska, E., \& Charitoudi, G. (2011). Women's entrepreneurship and local development: A case study in northern Greece. International conference on applied economics-ICOAE 2011.

Pollit, D. (2004). Hard listening and straight talking: the Aker Kvaerner approach. Human Resource Management, 12(5), 19-22. http://dx.doi.org/10.1108/09670730410546521

Puri, M., \& Robinson, D. T. (2006). Who are entrepreneurs and why do they behave that way? Manuscript submitted for publication. Retrieved from http://www.lse.ac.uk/fmg/documents/events/conferences/2006/comparativeAdvantage/751_Puri_Manju.pdf

Raffele, F. D. (2011). The 10 attributes of successful entrepreneurs. Hudson Valley Business Journal, 6-8.

Reynolds, O., Hay, M., \& Camp, S. M. (1999). Global entrepreneurship monitor. Kauffman Canter for Entrepreneurial Leadership.

Schepers, J., Wetzels, M., \& De Ruyter, K. (2005). Leadership styles in technology acceptance: Do followers practice what leaders preach? Managing Service Quality, 15(6), 496-508. http://dx.doi.org/10.1108/09604520510633998

Siti, N. A. M. (2005). Factors that has driven graduates and alumni of the University of Technology Malaysia venture into entrepreneurship. Master Thesis, University Of Technology Malaysia.

Still, L. V., \& Timms, W. (2000). Women's business: the flexible alternative work style for women. Women in Management Review, 15(5), 272-83. http://dx.doi.org/10.1108/09649420010372931 
Suaibah, A. B., Azlah, M. A., Hishamuddin, M. S., Rozeyta, O., Syaharizatul, N. M., \& Rosilla, M. J. (2005). Entrepreneurial activities among single mothers in the state of Johor. University Of Technology Malaysia.

Taormina, R. J., \& Lao, S. K. M. (2007). Measuring Chinese entrepreneurial motivation: personality and environmental psychological. International Journal of Entrepreneurial Behaviour and Research, 13(4), 200-221. http://dx.doi.org/10.1108/13552550710759997

Tenenhaus, M., Vinzi, V. E., Chatelin, Y. M., \& Lauro, C. (2005). PLS path modelling. Computational Statistics \& Data Analysis, 48, 159-205. http://dx.doi.org/10.1016/j.csda.2004.03.005

Teo, T. (2009). Examining the relationship between student teachers' self-efficacy beliefs and their intended uses of technology for teaching: A structural equation modelling approach. The Turkish Online Journal of Educational Technology, 8(4), 7-16.

Tracy, B. (2007, February). The way to wealth, part 1: The journey begins-success strategies of the wealthy entrepreneur (pp. 96-101). Entrepreneur Press.

Vesper, K. H. (1990). New Venture Strategies (2nd ed.). New Jersey: Prentice Hall.

Watson, K., Horgarth-Scott, S., \& Wilson, N. (1998). Small business start-ups: success factors and support implication. Journal of Entrepreneurial Behaviour and Research, 4(3), 217-238. http://dx.doi.org/10.1108/13552559810235510

\section{Copyrights}

Copyright for this article is retained by the author(s), with first publication rights granted to the journal.

This is an open-access article distributed under the terms and conditions of the Creative Commons Attribution license (http://creativecommons.org/licenses/by/3.0/). 